\title{
Wolman disease
}

INSERM

\section{Source}

INSERM. (1999). Orphanet: an online rare disease and orphan drug data base. Wolman disease. ORPHA:75233

Wolman disease represents the most severe manifestation of lysosomal acid lipase deficiency. Milder phenotypes as a whole are referred to as cholesterol ester storage disease (see this term). The acid lipase enzyme plays an essential role in lysosomal hydrolysis of both esterified cholesterol and triglycerides of lipoproteic orig in. In Wolman disease, the rarest form of acid lipase deficiency, these lipids accumulate in most tissues. 